\title{
Sandalwood spike disease: a brief synthesis
}

\author{
Jaime A. Teixeira da Silva'a ${ }^{1 a}$ Mafatlal M. Kher ${ }^{2 b}$, Deepak Soner ${ }^{2 c}$, M. Nataraj ${ }^{2 \mathrm{~d}}$ \\ ${ }^{1}$ P. O. Box 7, Miki-cho post office, Ikenobe 3011-2, Kagawa-ken, 761-0799, Japan \\ ${ }^{2}$ P. G. Department of Biosciences, Sardar Patel University, Sardar Patel Maidan, Vadtal Rd., P.O. Box 39, Vallabh Vidyanagar, Gujarat, \\ 388120, India \\ *Co-corresponding authors, E-mail: ajaimetex@yahoo.com; ${ }^{b}$ mafatlalmkher@gmail.com; cdeepaksoner@gmail.com; \\ dmnatarajspu@gmail.com
}

\begin{abstract}
Sandalwood spike disease (SSD) is likely to be the most destructive of known diseases to infect Indian sandalwood, Santalum album L., which is valued for its wood and scented essential oil derived from the heartwood. Even though the history of research on SSD extends for well over a century, most of the earlier work was primarily descriptive in macromorphological aspects. In 1969, a breakthrough was achieved by three independent research groups that confirmed the causal agent of SSD to be a phytoplasma. Despite this discovery, the identity of the causal agent was only confirmed by a single group using RFLP analysis and nested PCR of 16S rDNA. The phytoplasma that was identified showed high sequence similarity to aster yellows subgroup 16SrI-B. Tissue culture to derive disease-free clones and transgenic strategies to derive disease-resistant trees may be the only realistic solutions for ridding the limited S. album forests of SSD. This brief synthesis aims to stimulate greater interest in SSD, especially since sandalwood production has expanded to the Chinese mainland and to Australia.
\end{abstract}

Key words: Indian sandalwood, leaf curl, phytoplasma, Santalum album, spike, yellow disease.

Abbreviations: ELISA, enzyme-linked immunosorbent assay; RFLP, restriction fragment length polymorphism; SSD, sandalwood spike disease.

\section{Introduction and history}

Indian sandalwood (Santalum album L.), a highly valuable hardwood species of the Santalaceae, is popular for its fragrant wood and essential oil, and has importance in traditional and pharmaceutical medicine, as well as in the cosmetic and perfumery industries. Therefore, sustainable cultivation methods are required for the large-scale propagation and production of disease-free S. album plants. This can be successfully achieved using biotechnological approaches such as tissue culture (Teixeira da Silva et al. 2016). The survival and growth of seedlings, or of tissuecultured plantlets at the ex vitro stage, even those with an established root system, can be a difficult task due the hemiparasitic nature of $S$. album, which requires one or more specific hosts (Teixeira da Silva et al. 2016). There is evidence that $S$. album is susceptible to various insect pests (Sundararaj, Muthukrishnan 2011) and to sandalwood spike disease (SSD) (Arun Kumar, Joshi 2012; Kumar 2014). SSD of S. album was first reported in Coorg state, South India in 1899 (McCarthy 1900; Barber 1903) with over a million trees having been removed as a result of SSD from Mysore and Coorg states during 1903-1916. SSD, which is a critical disease of S. album, has been a topic of fascination for at least 100 years (McCarthy 1900; Barber 1903; Hole 1917; Ayyar 1918; Hodgson 1918; Hole 1918; Lushungton 1918; Jivana Rao 1920; Jivanna Rao 1921; Coleman 1923;
Hart, Rengaswamy 1926; Sreenivasaya 1930a; 1930b; Sreenivasaya, Rangaswami 1934; Sastri 1936).

Given the expanding nature of Santalum spp. and Indian sandalwood plantations throughout the Indian subcontinent and the Pacific (Teixeira da Silva et al. 2016), greater research into the causal agents, methods of transmission, molecular mechanisms underlying infectivity and methods to control or eradicate SSD would be beneficial. Research into SSD has stagnated in recent years, restricted to a very limited number of laboratories, primarily in India. This synthesis thus serves to add an impulse of interest among phytopathologists who might find this disease to be worthy of research.

\section{Discovery of the pathogen}

Research to investigate the causal organism for SSD spanned over more than half a century, from 1900 to 1968, but without any conclusive findings (Barber 1903; Brandis 1903; Hole 1917; Ayyar 1918; Fisher 1918; Hodgson 1918; Hole 1918; Lushungton 1918; Rama Rao 1918; Jivana Rao 1920; Jivanna Rao 1921; Coleman 1923; Hart and Rengaswamy 1926; Sreenivasaya 1930a; Sreenivasaya 1930b; Sreenivasaya, Rangaswami 1934; Sastri 1936; Ramaiah et al. 1961; Parthasarathi, Rao 1962; Parthasarathi et al. 1962; Ramaiah et al. 1962; Parthasarathi et al. 1963; Parthasarathi et al. 1966), even though various news articles 
were published in Nature ${ }^{\circ}$ during the same period (Editorial News, 1933a, 1933b, 1933c, 1940, 1941). Barber (1903) observed the following, with relation to SSD: "Results of my studies has been to trace the disease to the roots, but the exact cause of this diseased condition has not been determined", noting further that "It is difficult to see how effected trees could touch each other" referring to the steady progress of SSD from one plant to another as a communicable disease, irrespective of weather or soil conditions. Microscopic observations of S. album samples infected with SSD revealed a high accumulation of starch relative to healthy shoots, leading Barber to conclude that diseased plants die due to undigested nutrients (Barber 1903). He also observed that haustoria, which are specialized organs that assist in the hemiparasitic association of S. album with a host, were dead in the infected trees. In contrast, other researchers were of the opinion that SSD was not caused by infection, but was instead induced by an unbalanced circulation of sap (Hole 1917; Ayyar 1918) or a virus or viral-like microscopic organism (Coleman 1923; Dijkstra 1968). Dijkstra and Ie (1969) observed the presence of mycoplasma in the phloem sap of infected $S$. album trees, with Hull et al. (1969) and Verma et al. (1969) independently confirming the causal agent to be a mycoplasma. Mycoplasmas are now referred as phytoplasmas, i.e., prokaryotes lacking cell walls, infecting a wide range of plant taxa (Marcone 2015). Plant diseases caused by, or associated with, phytoplasmas occur in many agricultural and horticultural plants species of importance (Bertaccini et al. 2014; Arunkumar et al. 2016; Gurr et al. 2016). There are several reviews on various aspects of phytoplasma research (Marcone 2011; Kube et al.
2012; Marcone 2012; Bertaccini et al. 2014; Bertaccini 2015; Marcone 2015; Gurr et al. 2016; Trivedi et al. 2016).

\section{Symptoms}

SSD is characterised by chlorosis, a reduction in leaf size, and shortened internodes, causing leaves to become crowded on twigs with a "bushy" appearance and as stems standout stiffly, they acquire a spike-like appearance (Barber 1903; Hole 1917; Fig. 1A, 1B). Spiked plants do not bear flowers or fruits and trees generally die within 1 to 2 years after the appearance of symptoms at a young age (Swaminathan et al. 1998; Balasundaran, Muralidharan 2004; Upul Subasinghe, personal communication). Due to SSD, $S$. album populations in the forests of Kerala and Karnataka in India became considerably depleted (Swaminathan et al. 1998; Kumar 2014; Arunkumar et al.2016). Binu et al. (2014) also indicated that $S$. album production in India has been decreasing at an annual rate of $20 \%$ since 1995 for various reasons, including SSD, illicit felling and poor regeneration ability. Phytoplasmas are unculturable bacteria of the class Mollicutes; Candidatus ( $\mathrm{Ca}$.) that are associated with several symptoms, including "witches' broom (clustering of branches) of developing tissues; phyllody (retrograde metamorphosis of the floral organs to the condition of leaves); virescence (green coloration of non-green flower parts); bolting (growth of elongated stalks); formation of bunchy fibrous secondary roots; reddening of leaves and stems; generalized yellowing, decline and stunting of plants; and phloem necrosis" in many important food, vegetable, and fruit crops, ornamental plants, and timber and shade
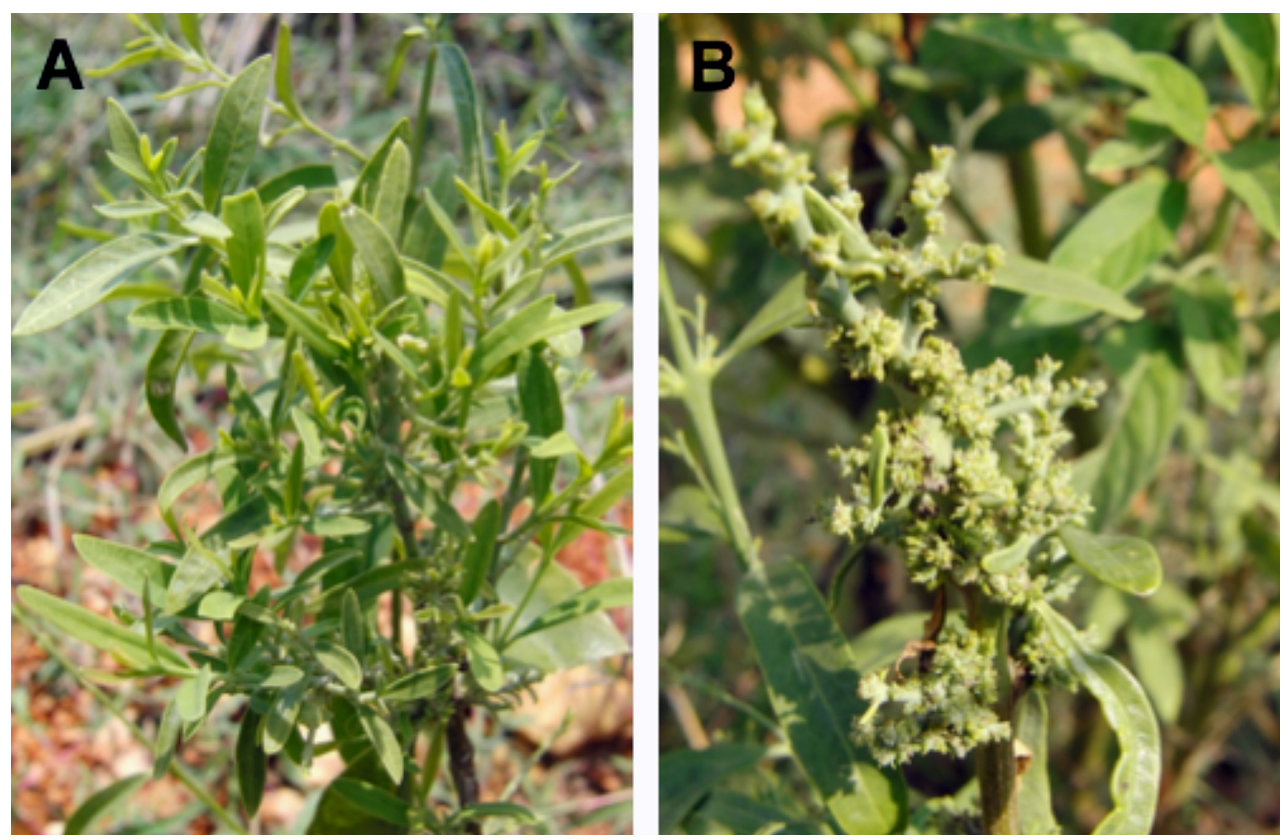

Fig. 1. Control sandalwood (Santalum album L.) plant (A) vs plant infected with sandal spike disease (B). Both photos from Arun Kumar, A.N., Joshi, G., 2012. Incidence of sandal spike symptoms in a one-year-old plantation in Karnataka. Curr. Sci. 103: 613-614. With kind permission from Dr. Arun A. N. Kumar. 
trees (Lee et al. 2000; Hogenhout et al. 2008; Bertaccini, Duduk 2009).

\section{Detection}

At the time when phytoplasmas were discovered, the diagnosis of plant pathogens was difficult since detection was based on the "observation of symptoms, insect or dodder/ graft transmission to host plant and electron microscopy of ultra-thin sections of the phloem tissue" (Bertaccini, Duduk 2009; Delić 2012). Serological diagnostic techniques for the detection of phytoplasmas began to emerge in the 1980's with direct and indirect enzyme-linked immunosorbent assay (ELISA)-based methods (Martin et al. 2000; Delić 2012). Methods based on ELISA and electron microscopy were reported by Balasundaran and Muralidharan (2004) and Thomas and Balasundaran (2001). ELISA could detect SSD six months before the expression of external symptoms (Balasundaran, Muralidharan 2004) but serological methods are insufficiently sensitive to detect various phytoplasmas (Delić 2012). PCR-based methods were used by Khan et al. $(2004 ; 2006 ; 2008)$ and Murli et al. (2013). Khan et al. (2008) revealed, following restriction fragment length polymorphism (RFLP) analysis, and using nested PCR of 16S rDNA (Khan et al. 2004), that two SSD strains showed high sequence similarity to the aster yellows subgroup 16SrI-B. PCR-based detection of phytoplasmas has been reviewed by Delić (2012). PCR-based methods revealed that $\mathrm{Ca}$. Phytoplasma cynodontis belongs to $16 \mathrm{SrI}$, which is one of the major groups of phytoplasmas associated with different plant species reported to be infected with phytoplasmas worldwide (Lee et al. 1998; Hogenhout et al. 2008; Bertaccini, Duduk 2009; Laimer et al. 2009; Marcone 2011; Rao et al. 2011; Delić 2012; Kube et al. 2012; Gurr et al. 2016). An understanding of phytoplasma ecology and epidemiology has increased as a result of the use of these PCR-based methods (Martin et al. 2000). Phytoplasmas can be detected by real-time PCR, nested-PCR and microarrays, but most of these need $16 \mathrm{~S}$ rRNA gene sequences (Hogenhout et al. 2008). About 40\% of open reading frames in phytoplasmas are disssimilar to GenBank sequences, and about 200 genes are conserved in the OY and AY-WB genomes (Bai et al. 2006). These distinctive genes can be useful targets for the detection of phytoplasmas (Hogenhout et al. 2008). Analyses of $16 \mathrm{~S}$ rRNA gene sequence analyses of about 200 phytoplasmas as well as members of $\mathrm{Ca}$. Phytoplasma asteris (16SrI group phytoplasmas) showed that about 30 clades could form in 80 monocotyledonous and dicotyledonous plant species (Hogenhout et al. 2008).

\section{Vectors and disease transmission}

Coleman (1917) first reported that SSD can be transmitted through grafting, and later added that haustorial connection of infected plants to a healthy host can be a possible means of SSD transmission (Coleman 1923). Grafting-based disease transmission was studied by histological observations (Dijkstra, van der Want 1970), in which cross sections of SSD-infected plants had phloem, the cambial area showed the presence of necrosed cells, while spongy parenchyma and pallisade tissues remained unaffected. Insect transmission of SSD was suspected by Coleman $(1917 ; 1923)$. Much later it was confirmed that SSD can be transmitted by insect vectors (Rangaswami, Sreenivasaya 1934). Insect vectors such as Moonia albimaculata (Dover, Appanna 1933; Sen-Sarma 1981; Sen-Sarma 1982), leafhopper Jassus indicus (Rangaswami, Griffith 1941; J. indicus is now known as Coelidia indica Walker (Marcone 2015)] and Nephotettix virescens Distant (Shivaramakrishnan, Sen-Sarma 1978; Sen-Sarma 1981; 1982). The transmission of phytoplasmas via insect vectors has bee extensively reviewed (Bai et al. 2006; Weintraub, Beanland 2006; Hogenhout et al. 2008; Marcone 2012). According to Weintraub and Beanland (2006), phytoplasmas are restricted to the phloem, therefore only insects that feed on phloem sap are responsible for the transmission of phytoplasmas. The physiology, biochemistry and molecular biology of the mechanism of the insect-phytoplasma-plant interaction has been described in detail by Weintraub and Beanland (2006), Kube et al. (2012), Marcone (2012) and Trivedi et al. (2016). Recently, Konnerth et al. (2016) reviewed the immunodominant membrane proteins found on the outer membrane of phytoplasmas, which can help to understand the phytoplasma-host interaction and its biology, virulence and mode of action.

\section{Control of SSD}

Absolute characterization of the phytoplasma responsible for SSD has still not been achieved and research is still required to reveal its definitive source and the best form of disease management (Bertaccini 2015; Food and Agriculture Organization of the United Nations 2015). Nayar (1980) reviewed various methods such as the use of heat therapy and chemical treatment using arsenic, benlate, or tetracyclines to control SSD, the latter having the most positive effect on SSD control. However, the application of tetracyclines to a large forest area is impractical. Thus, the most effective methods to eliminate SSD from sandalwood tissue are likely to be the use of tissue culture to create disease-free superior genotypes (Balasundaran, Muralidharan 2004), or to employ genetic transformation to introduce sequences that, once overexpressed, will reduce the phytoplasma titre, or the development of insect-resistant plants. Phytoplasma-induced disease can be controlled by proper management of insect vectors (Weintraub, Beanland 2006; Gurr et al. 2016), removal of infected plants from the field (Gurr et al. 2016), and of the application of plant growth-promoting microbes that not 
only enhance nutrient levels but also provide protection against microbial and insect vectors (Trivedi et al. 2016).

\section{Conclusions}

The mass production of Santalum spp., including Indian sandalwood, is now taking place not only on the Indian sub-continent, but also on mainland China and in Australia, for the production of high quality heartwood for use in the wood and perfume industries. The greatest limitation to field establishment lies with the selection of a suitable host as a result of the plant's hemiparasitic nature. SSD does not appear to pose a significant threat (yet) to Chinese and Australian cultures, but expanded research into understanding the causal agent and a molecular method to better control of the phytopathogen would be desirable.

\section{Acknowledgements}

We are thankful to Minal and Sujit (Sardar Patel University) for Providing Indian Forester literature. We also thank Dr. A. N. Arunkumar (Institute of Wood Science and Technology, Bangalore, India) and Dr. Upul Subasinghe (Department Forestry and Environmental Science, University of Sri Jayewardenepura, Sri Lanka) for insightful comments and discussion during a presubmission peer review. Finally, we thank Dr. A. N. Arun Kumar for kind permission to reuse two photos from Fig. 1 of Arun Kumar, A.N., Joshi, G., 2012. Incidence of sandal spike symptoms in a one-year-old plantation in Karnataka. Curr. Sci. 103, 613-614. The authors declare no conflicts of interest.

\section{References}

Arun Kumar A.N., Joshi G. 2012. Incidence of sandal spike symptoms in a one-year-old plantation in Karnataka. Curr. Sci. 103: 613-614.

Arunkumar A.N., Joshi G., Rao M.S., Rathore T.S., Ramakantha V. 2016. The population decline of Indian sandalwood and people's role in conservation - an analysis. In: Nautiyal S., Schaldach R., Raju K.V, Kaechele H., Pritchard B., Rao K.S. (eds) Climate Change Challenge (3C) and Social-EconomicEcological Interface-Building. Springer International Publishing, Switzerland, pp. 377-387.

Ayyar K.R.V. 1918. Is spike disease of sandal (Santalum album) due to an unbalanced circulation of sap? Indian For. 44: 316324.

Bai X., Zhang J., Ewing A., Miller S.A., Jancso R.A., Shevchenko D.V., Tsukerman K., Walunas T., Lapidus A., Campbell J.W., Hogenhout S.A. 2006. Living with genome instability: the adaptation of phytoplasmas to diverse environments of their insect and plant hosts. J. Bacteriol. 188: 3682-3696.

Balasundaran M., Muralidharan E.M. 2004. Development of spike disease resistant sandal seedlings through biotechnology involving ELISA technique and tissue culture. Kerala Forest Research Institute Report No. 258. pp. 1-56.

Barber C.A. 1903. Report on spike disease in sandalwood trees in Coorg. Indian For. 29: 22-31.

Bertaccini A. 2015. Phytoplasma research between past and future: what directions? Phytopathogenic Mollicutes 5: S1.

Bertaccini A. 2007. Phytoplasmas: diversity, taxonomy, and epidemiology. Front. Biosci. 12: 673-689.

Bertaccini A., Duduk, B. 2009. Phytoplasma and phytoplasma diseases: a review of recent research. Phytopathol. Mediterr. 48: 355-378.

Bertaccini A., Duduk B., Paltrinieri S., Contaldo N. 2014. Phytoplasmas and phytoplasma diseases: a severe threat to agriculture. Am. J. Plant Sci. 5: 1763-1788.

Binu N.K., Ashokan P.K., Balasundaran M., Kumar R.S., Nishant N. 2014. Responses in nutrition status of sandalwood (Santalum album L.) seedlings to shade, host and mycorrhizal association. In: Ramakantha V. (ed) International Seminar on Sandalwood: Current Trends and Future Prospects. Institute of Wood Science \& Technology: Indian Council of Forestry Research \& Eduction, Bangalore, p. 23.

Brandis D. 1903. Treatment of the sandal tree. Indian For. 29: 3-6.

Coleman L.C. 1923. The transmission of sandal spike. Indian For. 49: 6-9.

Coleman L.C. 1917. Spike disease of sandal. Department of Agriculture, Mysore. Mycology Series Bull. No.3. pp. 1-52.

Delić D. 2012. Polymerase chain reaction for phytoplasmas detection. In: Hernandez-Rodriguez D.P. (ed) Polymerase Chain Reaction. InTech, Shanghai.

Dijkstra J. 1968. The occurrence of inclusion bodies in leaf epidermis cells of sandal affected with spike disease. Netherlands J. Plant Pathol. 74: 101-105.

Dijkstra J., Ie T.S. 1969. Presence of mycoplasma-like bodies in the phloem of sandal affected with spike disease. Netherlands J. Plant Pathol. 75: 374-378.

Dijkstra J., van der Want J.P.H. 1970. Anatomical aspects of sandal plants affected with spike disease. Netherlands J. Plant Pathol. 76: 174-178.

Dover C., Appanna M. 1933. Entomological investigations on the spike disease of sandal. Indian For. Rec. 20: 1.

Editorial News 1941. Spike disease of sandal. Nature 147: 385-386. Editorial News 1940. Spike disease of sandal. Nature 145: 754-755.

Editorial News 1933a. Spike disease in Indian sandal. Nature 131: $720-721$.

Editorial News 1933b. Spike disease in Indian sandal. Nature 131: 89-90.

Editorial News 1933c. Insect transmission of spike disease. Nature 132: 592-593.

Fisher C.E.C. 1918. Cause of the spike disease of sandal (Santalum album). Indian For. 44: 571-575.

Food and Agriculture Organization of the United Nations. 2015. Sandalwood oil. Flavours and fragances of plant origin: Chapter-6 Sandalwood Oil. URL http://www.fao.org/docrep/ v5350e/V5350e00.htm. Accessed 18 November 2016.

Gurr G.M., Johnson A.C., Ash G.J., Wilson B.A.L., Ero M.M., Pilotti C.A., Dewhurst C.F., You M.S. 2016. Coconut lethal yellowing diseases: a phytoplasma threat to palms of global economic and social significance. Front. Plant Sci. 7: 1-21.

Hart W.C., Rengaswamy S. 1926. Preliminary investigation into the cause and cure of the spike disease in sandal (Sanatalum album) in the North Salem Division, Madras Presidency. Indian For. 52: 373-390.

Hodgson C.M. 1918. Spiked sandalwood. Indian For. 44: 66-71.

Hogenhout S.A., Oshima K., Ammar E.D., Kakizawa S., Kingdom H.N., Namba S. 2008. Phytoplasmas: bacteria that manipulate plants and insects. Mol. Plant Pathol. 9: 403-423.

Hole R.S. 1918. Spike disease of sandal. Indian For. 44: 325-334.

Hole R.S. 1917. Cause of the spike disease of sandal (Santalum album). Indian For. 40: 430-442. 
Hull R., Horne R.W., Nayar R.M. 1969. Mycoplasma-like bodies associated with sandal spike disease. Nature 224: 1121-1122.

Jivana Rao P.S.,1920. The cause of spike in sandal (Santalum album L.). Indian For. 46: 470-487.

Jivanna Rao P.S. 1921. The physiological anatomy of the spiked leaf in sandal (Santalum album L.). Indian For. 47: 352-360.

Khan J.A., Singh S.K., Ahmad J. 2008. Characterisation and phylogeny of a phytoplasma inducing sandal spike disease in sandal (Santalum album). Ann. Appl. Biol. 153: 365-372.

Khan J.A., Srivastava P., Singh S.K. 2006. Identification of a "Candidatus Phytoplasma asteris"-related strain associated with spike disease of sandal (Santalum album) in India. Plant Pathol. 55: 572-572.

Khan J.A., Srivastava P., Singh S.K. 2004. Efficacy of nested-PCR for the detection of phytoplasma causing spike disease of sandal. Curr. Sci. 86: 1530-1533.

Konnerth A., Boonrod K., Krczal G. 2016. Immunodominant membrane proteins of phytoplasmas. Microbiology 162: 12671273.

Kube M., Mitrovic J., Duduk B., Rabus R., Seemüller E. 2012. Current view on phytoplasma genomes and encoded metabolism. Sci. World J. 2012: 1-25.

Kumar M.A., 2014. Recurrence of sandal spike disease in Karnataka - an alert. Curr. Biot. 7: 253-255.

Laimer M., Lemaire O., Herrbach E., Goldschmidt V., Minafra A., Bianco P., Wetzel T. 2009. Resistance to viruses, phytoplasmas and their vectors in the grapevine in Europe: a review. J. Plant Pathol. 91: 7-23.

Lee I.M., Davis R.E., Gundersen-Rindal D.E. 2000. Phytoplasma: phytopathogenic mollicutes. Annu. Rev. Microbiol. 54: 221255.

Lee I.M., Gundersen-Rindal D.E., Bertaccini A. 1998. Phytoplasma: ecology and genomic diversity. Phytopathology 88: 1359-1366.

Lushungton P.M. 1918. Progress of spike investigation in the Southern circle, Madras Presidency during 1917-18. Indian For. 44: 439-460.

Marcone C. 2015. Current status of phytoplasma diseases of forest and landscape trees and shrubs. J. Plant Pathol. 97: 3-36.

Marcone C. 2012. Phytoplasmas: colonizing agents of plant phloem and insects. Phytopath. Mollicutes 2: 37-46.

Marcone C. 2011. Current status of phytoplasma diseases of medicinal and nutraceutical plants in Southern Italy. Bull. Insectol. 64: 233-234.

Martin R.R., James D., Lévesque C.A. 2000. Impacts of molecular diagnostic technologies on plant disease management. Annu. Rev. Phytopathol. 38: 207-239.

McCarthy 1900. Progress report of forest administration in Coorg. In: Pogress Report (Working Plans), pp. 9-12.

Murli R., Rangaswamy K.T., Chetan S.J. 2013. Silviculture management of Indian Sandalwood (Santalum album) problems and prospects. J. Plant Dis. Sci. 8: 1-4.

Nayar R. 1980. Control of spike disease of sandal. For. Pathol. 10: 236-242.

Parthasarathi K., Gupta S.K., Rao P.S. 1966. Studies on Sandal Spike. Part VII. Some useful stain tests for the diagnosis of the spike disease. Proc. Indian Acad. Sci. Sect. B 64: 152-156.

Parthasarathi K., Ramaiah P.K., Manjunatha T.R., Rao, P.S. 1962. Studies on sandal spike. III. The nitrate reductase activity in the normal and pathochemical states of sandal (Santalum album Linn.). Proc. Indian Acad. Sci. Sect. B 55: 285-289.

Parthasarathi K., Ramaiah P.K., Rao P.S. 1963. Studies on sandal spike. Part V. Ascorbic acid in the metabolism of sandal
(Santalum album L.) in health and disease. Proc. Indian Acad. Sci. Sect. B 57: 68-71.

Parthasarathi K., Rao P.S. 1962. Studies on sandal spike. II. Physiological significance of the disturbed iron balance in the spike disease of sandalwood (S. album Linn.). Proc. Indian Acad. Sci. Sect. B 55: 99-106.

Rama Rao M. 1918. Field investigation of "Spike disease" in sandal on the Kollimalai Hills. Indian For. 44: 58-65.

Ramaiah P.K., Parthasarathi K., Rao, P.S. 1962. Studies on sandal spike. IV. A histochemical study of the sandal (Santalum album Linn.) root haustoria in relation to mineral nutrition. Proc. Indian Acad. Sci. Sect. B 56: 111-113.

Ramaiah P.K., Parthasarathi K., Rao, P.S. 1961. Studies on sandal spike. I. The role of phenolic bodies in the metabolism of sandal (Santalum album Linn.) in health and disease. J. Sci. Ind. Res. 20: 273-275.

Rangaswami S., Griffith A.L. 1941. Demonstration of Jassus indicus (Walk) as a vector of the spike disease of sandal (Santalum album, Linn.). Indian For. 67: 387-394.

Rangaswami S., Sreenivasaya M. 1934. Insect transmission of spike disease of sandal (Santalum album Linn.). Curr. Sci. 4: 17-19.

Rao G.P., Mall S., Raj S.K., Snehi S.K. 2011. Review article: Phytoplasma diseases affecting various plant species in India. Acta Phytopathol. Entomol. Hung. 46: 59-99.

Sastri B.N. 1936. Physiology of the spike disease of sandal. Proc. Indian Acad. Sci. Sect. B 3: 444-449.

Sen-Sarma P.K. 1982. Insect vectors of sandal spike disease. Eur. J. For. Pathol. 12: 297-299.

Sen-Sarma P.K. 1981. Sandal spike disease - a vector transmitted tree disease. Proc. Indian Natl. Sci. Acad. B 46: 817-821.

Shivaramakrishnan V.R., Sen-Sarma P.K. 1978. Experimental transmission of spike disease of sandal by leaf hopper, Nephotettix virescens (Homoptera: Cicadellidae). Indian For. 104: 202-205.

Sreenivasaya M. 1930a. Occurrence of mannitol in spike disease of Santalum album (Linn.). Nature 126: 438.

Sreenivasaya, M., 1930b. Masking of spike-disease symptoms in Santalum album (Linn.). Nature 126, 957.

Sreenivasaya M., Rangaswami S. 1934. Field studies in the spike disease of sandal (Santalum album Linn). I-Observation on the natural dissemination of spike. Proc. Indian Acad. Sci. Sect. B 1: 143-154.

Sundararaj R., Muthukrishnan R. 2011. Population dynamics of some coccids (Coccoidea: Hemiptera) infesting sandal (Santalum album Linn) in Bangalore, India. J. For. Res. 22: 259-262.

Swaminathan M.H., Hosmath B.J., Mallesha B.B. 1998. The status of sandalwood in India-Karnataka. In: Radomiljac A.M., Ananthapadmanabha H.S., Welbourn R.M., Salyanarayana Rao K. (eds) Sandal and Its Products. ACIAR Proceedings No. 84, ACIAR. Australian Centre for International Agricultural Research, Canberra, Australia, pp. 3-5.

Teixeira da Silva J.A., Kher M.M., Soner D., Page T., Zhang X., Nataraj M., Ma G. 2016. Sandalwood: basic biology, tissue culture, and genetic transformation. Planta 243: 847-887.

Thomas S., Balasundaran M. 2001. Purification of sandal spike phytoplasma for the production of polyclonal antibody. Curr. Sci. 80: 1489-1494.

Trivedi P., Trivedi C., Grinyer J., Anderson I.C., Singh B.K. 2016. Harnessing host-vector microbiome for sustainable plant disease management of phloem-limited bacteria. Front. Plant Sci. 7: 1423. 
Verma A., Chenulu V.V., Raychaudhuri S.P., Prakash N., Rao P.S. 1969. Mycoplasma-like bodies in tissues infected with sandal spike and brinjal leaf. Indian Phytopathol. 22: 289-291.
Weintraub P.G., Beanland L. 2006. Insect vectors of phytoplasmas. Annu. Rev. Entomol. 51: 91-111. 